\title{
INTRA- AND INTEROBSERVER REPRODUCIBILITY OF THE RADIOGRAPHIC EVALUATION OF CRANIAL PARAMETERS
}

\author{
REPRODUTIBILIDADE INTRA E INTEROBSERVADORES DA AVALIAÇÃO RADIOGRÁFICA DE \\ PARÂMETROS CRANIANOS
}

\section{REPRODUCIBILIDAD INTRA E INTEROBSERVADORES DE LA EVALUACIÓN RADIOGRÁFICA DE PARÁMETROS CRANEALES}

\author{
igor Peluucl Pinto, ${ }^{10}$ Fáblo Antôno Vielra, ${ }^{2}$ David Del Curto, ${ }^{2}$ Renato Hiroshi Salvioni Ueta, ${ }^{2}$ Eduardo Barros Puertas ${ }^{2}$ \\ 1. Universidade Federal de São Paulo, Department of Orthopedics and Traumatology, São Paulo, SP, Brazil. \\ 2. Universidade Federal de São Paulo, Department of Orthopedics and Traumatology, Spine Pathology Group, São Paulo, SP, Brazil.
}

\begin{abstract}
Objective: To evaluate the intra- and interobserver reproducibility of radiographic cranial parameters. Method: A study of the reproducibility of the radiographic cranial parameters (cranial incidence, cranial tilt, cranial slope and spinocervical angle) of 40 patients by 4 observers with different levels of experience. Results: Cranial incidence $(\mathrm{Cl})$ showed poor intraobserver concordance; for the other cranial parameters, good to excellent concordance was observed. In the assessment of interobserver concordance, all the parameters analyzed showed statistical significance, with good $\mathrm{Cl}$ concordance. Conclusion: Cranial parameters are easily reproducible by orthopedists with different levels of experience. Cl showed good interobserver concordance, but only reasonable intraobserver concordance among more experienced observers. Level of evidence IV; Diagnostic Study.
\end{abstract}

Keywords: Spinal Curvatures; Spine; Postural Balance.

\section{RESUMO}

Objetivo: Avaliar a reprodutibilidade intra e interobsenvadores dos parâmetros radiográficos cranianos. Métodos: Estudo de mensuração da reprodutibilidade da avaliação radiográfica de parâmetros cranianos (incidência craniana, inclinação craniana, slope craniano e ângulo espinocervical) de 40 pacientes, por quatro observadores com diferentes níveis de experiência em duas ocasiões distintas. Resultados: Na concordância intraobsenador, a incidência craniana (IC) mostrou concordância ruim; nos demais parâmetros cranianos, observou-se concordância boa a excelente. Na avaliação de concordância interobsenadores, todos os parâmetros analisados apresentaram significância estatística, com boa concordância da IC. Conclusão: Os parâmetros cranianos são facilmente reprodutiveis por ortopedistas em diferentes estágios de formação. A IC tem boa concordância interobsenador, porém concordância apenas razoável na análise de intraobsenvadores mais experientes. Nível de evidência IV; Estudo Diagnóstico.

Descritores: Curvaturas da Coluna Vertebral; Coluna Vertebral; Equilíbrio Postural.

\section{RESUMEN}

Objetivo: Evaluar la reproducibilidad intra e interobservadores de los parámetros radiográficos craneales. Métodos: Estudio de medición de la reproducibilidad de la evaluación radiográfica de parámetros craneales (incidencia craneal, inclinación craneal, slope craneal y ángulo espinocervical) de 40 pacientes, por cuatro observadores con diferentes niveles de experiencia en dos ocasiones distintas. Resultados: En la concordancia intraobservador, la incidencia craneal (IC) mostró concordancia mala; en los demás parámetros craneales, se observó concordancia de buena a excelente. En la evaluación de concordancia interobservadores, todos los parámetros analizados presentaron significancia estadística, con buena concordancia de la IC. Conclusión: Los parámetros craneales son fácilmente reproducibles por los ortopedistas en diferentes etapas de formación. La IC tiene buena concordancia interobservador, aunque concordancia sólo razonable en el análisis de intraobservadores con más experiencia. Nivel de evidencia IV; Estudio Diagnóstico.

Descriptores: Curvaturas de la Columna Vertebral; Columna Vertebral; Equilibrio Postural.

\section{INTRODUCTION}

Loss of sagittal balance affects patients with a wide variety of spinal pathologies. Its association with significant pain and limited activities of daily life result in a reduction in quality of life of the patients who suffer from this condition. ${ }^{1}$
The cervical spine is the spinal region with the greatest mobility in the sagittal plane and it uses compensatory mechanisms to maintain the horizontal view when its physiological balance is affected. ${ }^{2}$ However, understanding these mechanisms is still a challenge for the spine surgeon. ${ }^{3}$ Nevertheless, radiographic parameters have been 
proposed to evaluate and characterize craniocervical sagittal balance, many of which are as yet little known or without proven relevance.

Several authors have demonstrated that pelvic incidence is an important morphological factor, influencing lumbar lordosis and thoracic kyphosis. ${ }^{4-6}$ Through analogy to the lumbopelvic complex, Le Huec et al. defined morphological sagittal balance parameters for the craniocervical complex: the angle of cranial incidence $(\mathrm{Cl})$, cranial slope (CS), cranial tilt (CT) and the spinocranial angle (SCA). ${ }^{7}$

Due to the growing importance of craniocervical alignment in overall sagittal balance and the scarcity of studies that address these parameters, this study was developed with the aim of evaluating the intra- and interobserver reproducibility of the cranial radiographic parameters.

\section{METHODS}

This was a study to measure the reproducibility of the radiographic evaluation of cranial parameters, submitted to and approved by the Institutional Review Board of our institution as opinion number 3.828.083 (CAAE 26041919.2.0000.5505). The informed consent form was applied for access to electronic medical records and use of the radiographic images.

Lateral cervical spine radiographs of 40 patients were randomly selected from the database of the Department of Imaging Diagnostics (DDI) of the Universidade Federal de São Paulo - Escola Paulista de Medicina (UNIFESP - EPM) by an independent observer. Radiographs of patients of both sexes between 18 and 60 years of age and without distinction by race were included. The exclusion criteria were skeletally immature patients, patients with congenital or idiopathic deformities, poor quality examinations, patients with previous cervical vertebral fractures, and patients who had undergone cervical spine surgery.

The radiographic cranial parameters were measured according to the proposal of Le Huec et al. ${ }^{7}$ and are illustrated in Figures 1 to 3: - Cranial Incidence (Cl): the angle formed between a line perpendicular to the midpoint of the McGregor line and another connecting this point to the sella turcica.

- Cranial Tilt (CT): the angle formed by a vertical line and a line that connects the midpoint of the McGregor line to the sella turcica. - Cranial Slope (CS): the angle formed between a horizontal line and the McGregor line.

- Spinocranial Angle (SCA): the angle formed between the slope of $\mathrm{C} 7$ and a straight line that connects the center of the lower $\mathrm{C} 7$ endplate to the center of the sella turcica.

All the images were printed in high definition and four observers performed the analysis of the radiographical examinations after being briefed about the pertinent radiographic landmarks. Their respective backgrounds were observer 1 - an orthopedic spine surgeon with more than 5 years of practice; observer 2 - an orthopedic spine surgeon with less than 5 years of practice; observer 3 - an orthopedist specializing in spine surgery; and observer $4-a$ third-year resident in orthopedics and traumatology. Each observer performed 2 series of measurements, with an interval of 2 weeks and with the imaging examinations in random order.

The intraclass correlation coefficient (ICC) and a confidence interval of $95 \%$ were used for the analysis of intra- and interobserver concordance. The ICC was interpreted in accordance with the guidelines proposed by Cicchetti. (Table 1$)^{8} \mathrm{~A}$ statistical significance of $5 \%$ was adopted for all analyses, with $p$-values $<0.05$ considered significant. All the analyses were conducted using IBM SPSS Statistics ${ }^{\odot}$ version 20.0 software.

\section{RESULTS}

All the observers measured 40 radiographs on two distinct occasions. In the intraobserver concordance, the cranial incidence showed poor reliability in the analyses of observer 4 and moderate reliability in observers 1,2 and 3 . In the other cranial parameters good to excellent reliability was observed in the analysis of all the observers. (Table 2) When we grouped the analysis of all the observers, the $\mathrm{Cl}$ also was shown to have poor concordance.

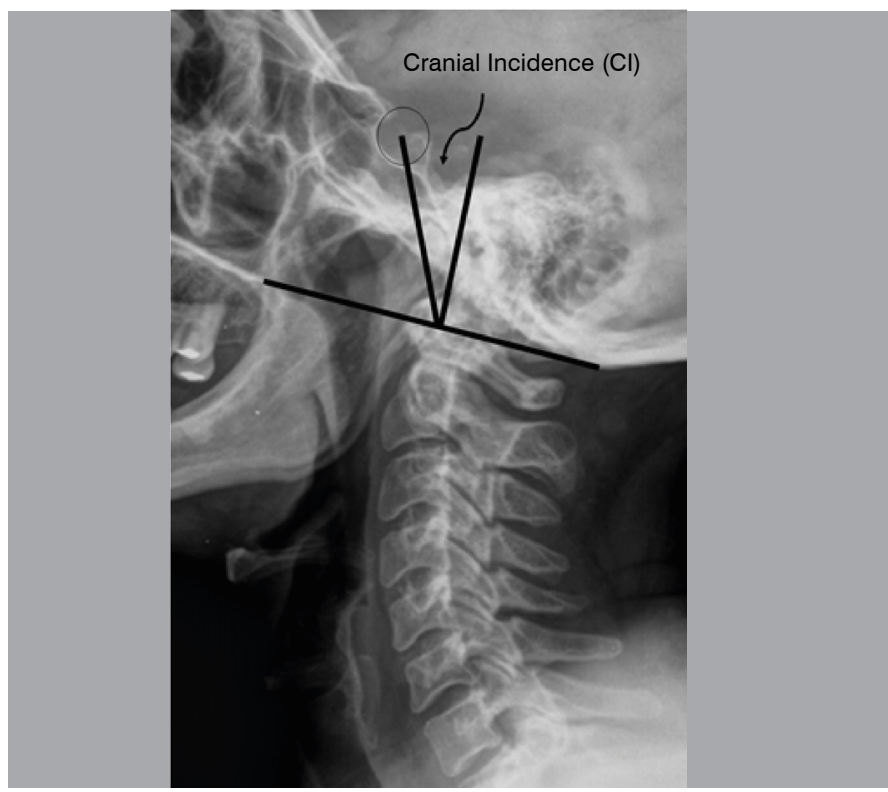

Figure 1. Measurement of Cranial Incidence (Cl).

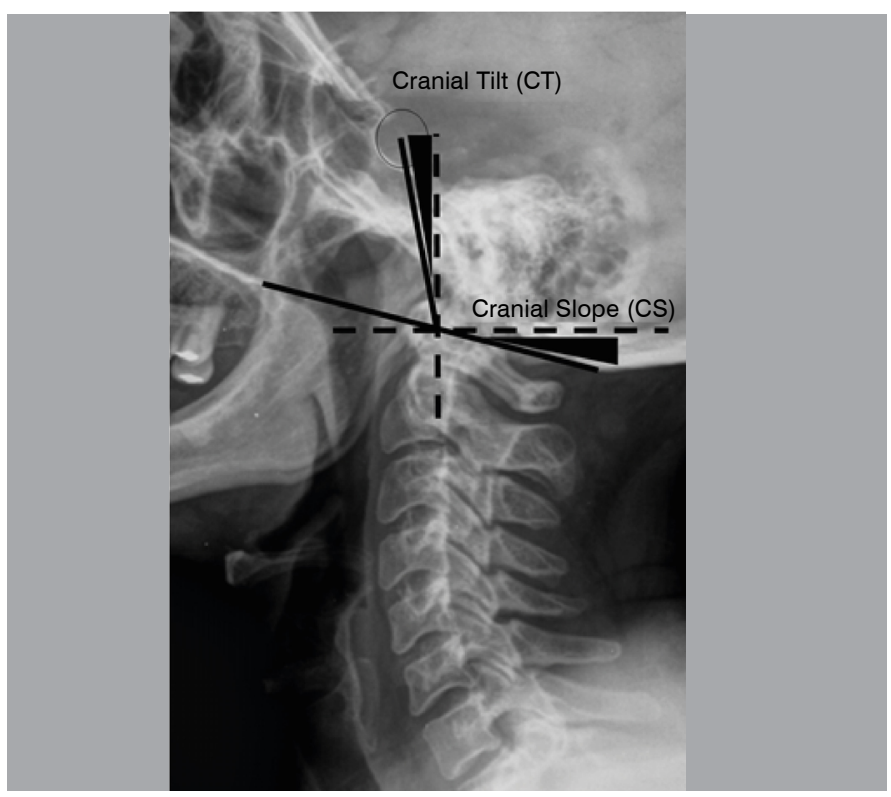

Figure 2. Measurement of Cranial Tilt (CT) and Cranial Slope (CS).

In the interobserver concordance, statistical significance was observed in relation to all the radiographic parameters analyzed, with a correlation coefficient of 0.6 for cranial incidence, indicating good concordance. (Table 3)

\section{DISCUSSION}

Despite the growing interest in the sagittal balance of the spine in recent decades, there is still a scarcity of information about the craniocervical parameters that are definitive for a satisfactory and pertinent outcome. ${ }^{9}$ It is known that the sagittal balance of the cervical spine can impact the clinical results of cervical surgery ${ }^{10}$ and its loss is associated with a reduction in patient quality of life. ${ }^{1}$ However, the compensatory mechanisms of the cervical spine are not yet entirely understood by spine surgeons. ${ }^{3}$

Le Huec et al. demonstrated that the cervical spine is the final adaptive factor in maintaining cranial balance. They defined normal values for the different cranial parameters ${ }^{7}$ and stated that the spinocranial angle (SCA) is one of the most relevant parameters for analysis of cervical sagittal balance. ${ }^{9}$ With our study, we can 


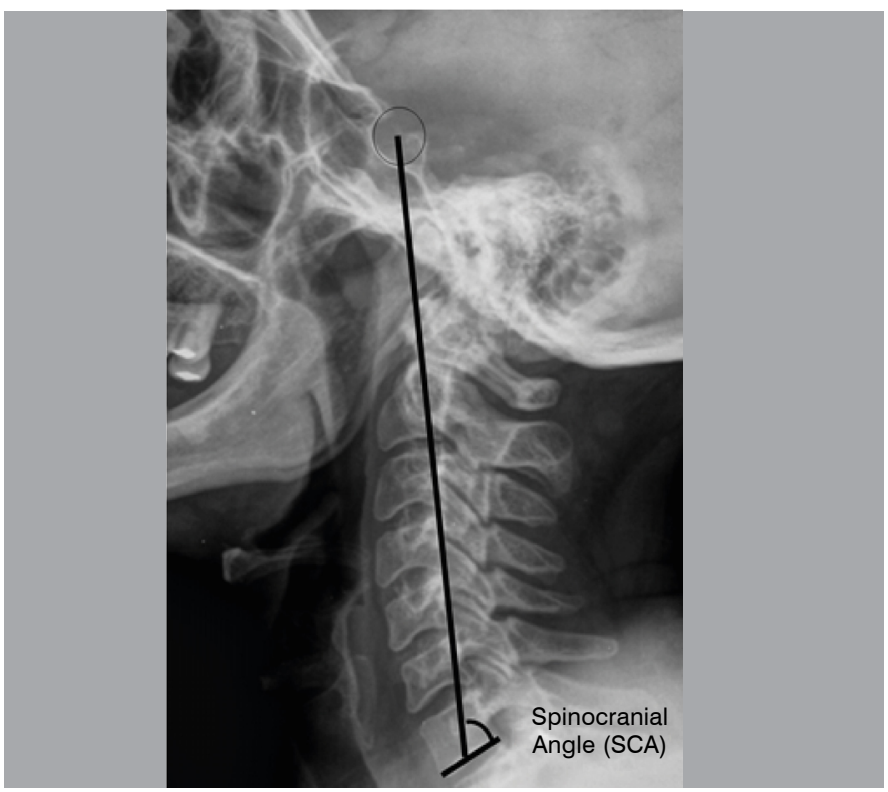

Figure 3. Measurement of the Spinocranial Angle (SCA).

Table 1. Categorization of the Intraclass Correlation Coefficient (ICC).

\begin{tabular}{c|c}
\hline ICC & Concordance \\
\hline$<0.4$ & Poor \\
\hline $0.4-0.59$ & Moderate \\
\hline $0.6-0.74$ & Good \\
\hline $0.75-1.0$ & Excellent \\
\hline
\end{tabular}

state that the SCA is an easily reproducible cranial parameter with excellent intra- and interobserver concordance.

Cranial incidence also seems to be reliable for the analysis of cervical sagittal balance, presenting well-defined variations according to the amplitude of the cervical lordosis. ${ }^{7}$ In this study, the $\mathrm{Cl}$ showed good interobserver concordance, but poor concordance in overall intraobserver agreement. This may be related to the greater ease in identifying anatomical structures for the cervical region reference lines by the more experienced observers as compared to the resident in orthopedics.
Table 2. Intraobserver concordance analysis

\begin{tabular}{c|c|c|c|c|c}
\hline \multicolumn{2}{l|}{} & CI & CS & CT & SCA \\
\hline Observer 1 & ICC & 0.520 & 0.987 & 0.882 & 0.964 \\
\hline & P-value & 0.012 & $<0.001$ & $<0.001$ & $<0.001$ \\
\hline Observer 2 & ICC & 0.512 & 0.992 & 0.923 & 0.961 \\
\hline & P-value & 0.024 & $<0.001$ & $<0.001$ & $<0.001$ \\
\hline Observer 3 & ICC & 0.536 & 0.957 & 0.790 & 0.853 \\
\hline & P-value & 0.009 & $<0.001$ & $<0.001$ & $<0.001$ \\
\hline Observer 4 & ICC & 0.274 & 0.816 & 0.620 & 0.888 \\
\hline & P-value & 0.161 & $<0.001$ & 0.002 & $<0.001$ \\
\hline All & ICC & 0.221 & 0.946 & 0.851 & 0.917 \\
\hline & P-value & 0.058 & $<0.001$ & $<0.001$ & $<0.001$ \\
\hline
\end{tabular}

Table 3. Interobserver concordance analysis.

\begin{tabular}{c|c|c|c|c|c}
\hline \multicolumn{2}{l|}{} & CI & CS & CT & SCA \\
\hline Interobserver & ICC & 0.602 & 0.944 & 0.885 & 0.959 \\
\hline & P-value & $<0.001$ & $<0.001$ & $<0.001$ & $<0.001$ \\
\hline
\end{tabular}

Not using software to take the measurements can be considered a limitation of the study. However, all the images were previously worked on by an independent observer to facilitate identification of the anatomical landmarks of interest. Additionally, the study sample, while satisfactory, consisted of only 40 radiographs.

\section{CONCLUSION}

Cranial parameters are easily reproducible by orthopedists at different education and experience levels. The SCA had excellent intra- and interobserver agreement. The $\mathrm{Cl}$ had good interobserver concordance, but only moderate agreement in the intraobserver analysis of more experienced observers. Further studies are needed to better understand the importance of these parameters in spine surgery.

All authors declare no potential conflict of interest related to this article.

CONTRIBUTION OF THE AUTHORS: Each author made significant individual contributions to this manuscript. IPP: writing, data analysis, intellectual concept and preparation of the entire research project; FAV: writing, data analysis, intellectual concept and preparation of the entire research project; RHSU: intellectual concept, data analysis and review; DDC: data analysis and review; EBP: intellectual concept and review.

\section{REFERENCES}

1. Glassman SD, Berven S, Bridwell K, Horton W, Dimar JR. Correlation of radiographic parameters and clinical symptoms in adult scoliosis. Spine (Phila Pa 1976). 2005;30(6):682-8. doi: 10.1097/01.brs.0000155425.04536.f7.

2. Cecchinato R, Langella F, Bassani R, Sansone V, Lamartina C, Berjano P. Variations of cervical lordosis and head alignment after pedicle subtraction osteotomy surgery for sagittal imbalance. Eur Spine J. 2014;23 Suppl 6:644-9. doi: 10.1007/s00586-014-3546-x.

3. Barrey C, Jund J, Noseda O, Roussouly P. Sagittal balance of the pelvis-spine complex and lumbar degenerative diseases. A comparative study about 85 cases. Eur Spine J. 2007;16(9):1459-67. doi: 10.1007/s00586-006-0294-6.

4. Roussouly P, Gollogly S, Berthonnaud E, Dimnet J. Classification of the normal variation in the sagittal alignment of the human lumbar spine and pelvis in the standing position. Spine (Phila Pa 1976). 2005;30(3):346-53. doi: 10.1097/01.brs.0000152379.54463.65.

5. Lafage V, Schwab F, Skalli W, Hawkinson N, Gagey PM, Ondra S, et al. Standing balance and sagittal plane spinal deformity: analysis of spinopelvic and gravity line parameters. Spine (Phila Pa 1976). 2008;33(14):1572-8. doi: 10.1097/BRS.0b013e31817886a2
6. Le Huec JC, Aunoble S, Philippe L, Nicolas P. Pelvic parameters: origin and significance. Eur Spine J. 2011;20 Suppl 5:564-71. doi: 10.1007/s00586-011-1940-1.

7. Le Huec JC, Demezon H, Aunoble S. Sagittal parameters of global cervical balance using EOS imaging: normative values from a prospective cohort of asymptomatic volunteers. Eur Spine J. 2015;24(1):63-71. doi: 10.1007/s00586-014-3632-0.

8. Cicchetti DV. Guidelines, criteria, and rules of thumb for evaluating normed and standardized assessment instruments in psychology. Psychol Assess. 1994;6(4):284-90 doi:10.1037/1040-3590.6.4.284

9. Ling F, Chevillotte T, Leglise A, Thompson W, Bouthors C, Le Huec J. Which parameters are relevant in sagittal balance analysis of the cervical spine? A literature review. Eur Spine J. 2018;27(Suppl 1):8-15. doi: 10.1007/s00586-018-5462-y.

10. Gum JL, Glassman SD, Douglas LR, Carreon LY. Correlation between cervical spine sagittal alignment and clinical outcome after anterior cervical discectomy and fusion. Am J Orthop (Belle Mead NJ). 2012;41(6):E81-4 